\title{
INCLUSIVE BUSINESS MODEL - STRATEGIC CHALLENGE FOR AGRIBUSINESS CLUSTER MANAGEMENT
}

\begin{abstract}
The aim of the article is to present the key assumptions of the inclusive business model and the justification for its application in agribusiness cluster. Scientific considerations were conducted on the basis of theoretical and empirical research results. The starting point in the accepted range of considerations was a well-known statement that well-managed clusters can shaping the competitiveness not only of its members but also the economy and contributing to strengthening economic, social and territorial cohesion.

The article consists of three integral parts, in which the strategic dimension of an agribusiness cluster, the essence, and significance of the inclusive business model and the existing experiences of the AgroBio Cluster in the area of implementation of this model were characterised. The authors show that the concept of agribusiness clusters provides a solid basis for adopting a new way of thinking about creating the competitiveness of food economy entities, taking into account social needs and values. Different types of clusters, in particular, agribusiness clusters, can create inclusive groups when an open membership is ensured in their environment, and the willingness of cluster cooperation is a decisive factor to belong to the cluster. The key factor in the development of clusters is the inclusive ties, which connect people and organisations from different environments. Thus, they determine the quality and intensity of partnership in the cluster, strengthening the involvement of the cluster community. These and other premises presented in the article, referring to the specificity of agribusiness cluster functioning, confirm emphatically that the inclusive business model may prove to be a valuable tool in the process of achieving the cluster goals, especially in less-developed regions. Although the implementation of this model is still a strategic challenge in cluster management, its numerous practical advantages justify the focus of the coordinator and cluster members efforts on shaping the inclusive business and sustainable supply chain within the cluster. In this process, measurable public support is required, both financial and nonfinancial.
\end{abstract}

Keywords: cluster, agribusiness, inclusive, management, value, development.

\section{INTRODUCTION}

Almost from the beginning of the 21st century, the subject literature often shows that vibrant and active agribusiness clusters are of strategic importance for the long-term trans-

${ }^{1}$ Bogusław Bembenek, PhD, Faculty of Management, Rzeszow University of Technology, Poland Rzeszów, corresponding author, e-mail: bogdanb@prz.edu.pl

2 Katarzyna Kowalska, PhD student, World Economy Research Institute, Warsaw School of Economics, Poland - Warsaw, Vice-President of UNIMOS Foundation, e-mail: kkowalska@unimos. global 
formation process in the food economy. These structures are mainly co-created by agribusiness entities, traditional agricultural sector, including micro, small and medium enterprises (SMEs), agricultural holdings, R\&D sector entities and social organisations related to agriculture and food production. Their coordinators, striving to provide them with favourable conditions for the development and effective use of their resources, often have to assess to what extent the existing cluster business model is inclusive. This is very important, considering the fact that the inclusive business model helps, among others in overcoming limitations in access to resources and ensuring equal opportunities for smallholders and SMEs in achieving their socio-economic goals. The development of an activity model that is adequate to meet the existing and future needs of the cluster is an example of a strategic challenge. The process requires the involvement of the coordinator and cluster members as well as external key stakeholders such as public authorities (local and national government) and investors.

The aim of the article is to present the basic assumptions of the inclusive business model and the justification for its application in agribusiness clusters. As part of such a goal, answers to three research questions were sought:

- what distinguishes activity of agribusiness clusters?

- what is the current significance of an inclusive business model for agribusiness cluster development?

- how does a cluster coordinator (cluster organisation) shape the favourable conditions within a cluster for inclusive business development?

The scientific considerations were based on selected results of theoretical and empirical research. In the research process, a very useful methods applied were a desk research and case study. The source of data in qualitative research was the own experience of the coauthor ${ }^{3}$ of the article in the managing of an AgroBio Cluster. The case study was determined in a significant part by the phenomenological paradigm ${ }^{4}$, due to the holistic view of the studied phenomenon and the generation of knowledge on the basis of participant observation (the observer participates in ongoing activities and records observations). The choice of case study method resulted from the conviction of the authors of the article that the presented case concerning the implementation of the main assumptions of the inclusive business model within agribusiness cluster may be a source of inspiration for various cluster stakeholders.

\footnotetext{
${ }^{3}$ K. Kowalska - cluster manager of AgroBio Cluster, co-founder of Unimos-Global, i.e. European cross-sectoral organisation focused on building trust-based partnerships between business, science, administration and clusters that foster growth and international development. Unimos is an institutional coordinator of AgroBio Cluster.

${ }^{4}$ Phenomenology is concerned with attending to the way things appear to individuals in experience. It aims at identifying the essential components of phenomena or experiences which make them unique or distinguishable from others. Phenomenology studies try to recognise what essential components make a given phenomenon special (or unique). Therefore, they will thus focus on how people perceive and talk about objects and events, rather than describing phenomena according to a predetermined categorical system, conceptual and scientific criteria. This involves 'bracketing' one's preconceptions and allowing phenomena to speak for themselves. The theoretical orientation which phenomenological analysis relies upon is idiography. The fundamental principle behind the idiographic approach is to explore every single case, before producing any general statements. I. Pietkiewicz, J.A. Smith, A practical guide to using interpretative phenomenological analysis in qualitative research psychology, "Psychological Journal" 2012, no. 18 (2), pp. 361-363.
} 


\section{CONCEPTUAL FRAMEWORK OF AGRIBUSINESS CLUSTER}

Agribusiness cluster is widely discussed in the existing scientific literature because its concept is closely related to development of agro-food economy. The economic literature provides many definitions of what a agribusiness cluster is, for example:

- geographical proximity and concentration of producers and institutions that are engaged in the food and agricultural sector and that inter-connect and build value networks, either formally or informally, when addressing common challenges and pursing common opportunities ${ }^{5}$;

- organisation that connects key actors including farmers and local entrepreneurs (involved in supplier and channel value chains), businesses indirectly serving agriculture or ecosystem services stemming from food production and also bankers (financial services), entities conducting R\&D activity or business development services in the same region ${ }^{6}$;

- concentration of a critical mass of agricultural producers, food industry enterprises and their servicing infrastructure organisations operating in the agro-food and other markets in a comfortable business environment, supported by the authorities, while their relations are in equal measure cooperative and competitive in nature and give rise to synergistic ecological and socio-economic effect, enhancing the competitiveness of the territory ${ }^{7}$;

- formal or informal organisation, comprised of a set of entities from industries farm production (farming business), farm-related industries (supporting industries), and other agribusiness partners ${ }^{8}$.

Agribusiness cluster is characterised by specialisation and different dimension of proximity, e.g. geographical, organisational, social, institutional, technological, and cognitive. Firms in a cluster draw a productive advantage from their geographic concentration ${ }^{9}$. Overall, researchers situate geographic proximity as an antecedent to positive externalities in clusters, and especially to innovation ${ }^{10}$. Cluster formation and development is a learning by doing process, where productivity is achieved through coopetition (describing cooperative competition) and innovations. Cluster evolve over time. Its development is a lengthy process, which evolves in different ways across time and space ${ }^{11}$.

${ }^{5}$ E. Galvez-Nogales, Agro-based clusters in developing countries: staying competitive in a globalized economy, Food and Agriculture Organization of the United Nations, Rome 2010, p. 5.

6 A. Alhassan, J.S. Bapule, O. Gyasi, G.A. Mills, J. Nketiah, R. Yeboah, Facilitating agribusiness cluster development at grassroot level, International Centre for Development Oriented Research in Agriculture, Wageningen 2007, p. 7.

7 E. Dorzhieva, E. Dugina, The formation of agro-food clusters as a competitiveness growth factor, "International Journal of Economics and Financial Issues" 2015, no. 5, p. 241.

8 https://www.missourieconomy.org/pdfs/agribusiness.pdf (access: 1.11.2017).

9 D. Shabazian, G. Ballard-Rosa, A. Holmqvist, L. Ormiston, Food and Agriculture cluster assessment, The Sacramento Area Council of Governments, Sacramento 2016, p. 9.

${ }^{10}$ C. Geldes, Ch. Felzensztein, E. Turkina, A. Durand, How does proximity affect interfirm marketing cooperation? A study of an agribusiness cluster, "Journal of Business Research" 2015, no. 68, p. 265.

${ }^{11}$ M. Alidou, M. Lem, T. Schrader, F. Zeeuw, Local entrepreneurship, agribusiness cluster formation and the development of competitive value chains, Berenschot, Koutiala 2010, p. 20; R. Ramon-Munoz, The growth of an agribusiness cluster in Catalonia: evidence from the Olive Oil Industry, "The Low Countries Journal of Social and Economic History" 2016, no. 13 (4), p. 42. 
Agribusiness cluster has a nature of eco-cluster, if it is a part of eco-business or green economy in general. Through the eco-innovations and eco-efficiency strategies it creates new environmentally friendly products and services. Eco-clustering is inspired by the cyclic processes in ecosystems ${ }^{12}$.

Practitioners and scholars argue that clustering in the agricultural sector presents many benefits, such as creating an enabling environment for cooperation between smallholder households and SMEs, facilitating the diffusion of innovations, and acting as a means to efficiently channel public support to increase competitiveness in the agricultural sector. Active agribusiness cluster focus on lower transaction costs, better meeting consumer demands, and increasing productivity ${ }^{13}$. Efficient linkages and integration within the commodity value chains agribusiness cluster in increases incomes of farmers and local entrepreneurs, allows for multiplier effects, economic growth, and development new agroenvironmental technologies ${ }^{14}$. A well-developed concentration of related agribusiness spurs three important activities: increased productivity (specialised inputs, access to information, synergies, public goods), more rapid innovation (cooperative activities in R\&D and competitive striving), and new business formation through filling in niches and expanding the boundaries of the cluster map ${ }^{15}$. Dynamic agribusiness cluster is critical factor for a successful development of agriculture and food economy. Thus, it seeks to realise similar goals, but at multiple value chain stage ${ }^{16}$. Smallholder households represent one often overlooked actor in agribusiness value chains, and yet there are many reasons why smallholders might be important value chain actors ${ }^{17}$ :

- firstly, they tend to have lower labour costs and higher productivity for mixed-cropping systems with higher levels of crop diversity,

- secondly, they are the main food producers in developing countries, increased smallholder agricultural production means more food enters the marketplace, leading to lower food prices and better diets,

- thirdly, gross domestic food and nutrient providers have therefore a special role to play in the global efforts to improve food and nutrition security.

Before the industrial revolution, smallholder farmers were the key actors in the food chain. After that, when agro producers started to produce bulk commodities for the processing sector, farmers became more and more connected with and dependent from other actors within agribusiness value chains ${ }^{18}$.

12 A. Sobol, The perspectives for eco-clusters development in Poland, "Central and Eastern European Journal of Management and Economics" 2016, vol. 4, no. 1, p. 68.

${ }^{13}$ E. Galvez-Nogales, Agro-based clusters ..., op. cit., p. 1.

${ }^{14}$ A. Alhassan, J.S. Bapule, O. Gyasi, G.A. Mills, J. Nketiah, R. Yeboah, Facilitating agribusiness cluster ..., op. cit., p. 7.

15 F. Theus, D. Zeng, Agricultural clusters, [in:] Agricultural innovation systems, The World Bank, Washington 2012, p. 399.

${ }^{16}$ Ch. Clark, J. Rudder, K. Javid, A. Lawrence, M. Neidhart, P. Biscaye, K. Panhorst-Harris, T. Reynolds, C.L. Anderson, Agribusiness development clusters, Evans School of Public Affairs, University of Washington, Evans School Policy analysis and Research, Seattle 2015, p. 5.

17 Ibidem, pp. 5-6; B.M. Dioula, H. Deret, J. Morel, E. Vachat, V. Kiaya, Enhancing the role of smallholder farmers in achieving sustainable food and nutrition security, International Conference on Nutrition - better nutrition better lives, Paris 2013, p. 6.

${ }_{18}$ M. Molema, Y. Segers, E. Karel, Introduction: Agribusiness clusters in Europe, $19^{\text {th }}$ and $20^{\text {th }}$ Centuries, "The Low Countries Journal of Social and Economic History" 2016, no. 13 (4), p. 10. 


\section{MEANING AND SIGNIFICANCE OF INCLUSIVE BUSINESS MODEL}

The idea inclusive business emerged in the 1990s like the M. Porter's cluster theory. It is often analysed in different contexts of business ethics, sustainable development, corporate citizenship, and social economy. The study of inclusive business related to inclusive markets $^{19}$, inclusive growth ${ }^{20}$ and shared value ${ }^{21}$, represent most vibrant topics in current economic literature. Inclusive business aims to address development challenges and enhance the socio-economic wellbeing through focus on corporate social responsibility and value chain management ${ }^{22}$. In parallel, inclusive business is becoming an area of focus for governments, politicians, finance institutions, non-government organisations (NGOs), $\mathrm{R} \& \mathrm{D}$ sector and cluster coordinators (cluster organisations). Its strategic challenge is dynamic spreading around the world ${ }^{23}$.

The inclusive business approach frequently refers to additional measures in relation to value of social entrepreneurship or social economy, which can be described as wider government policies and strategies ${ }^{24}$. According to S. Kelly, N. Vergara and H. Bammann, the supporting business models at the local level, where usually value chain linkages are at their weakest, can strengthen the overall competitiveness of a global value chain. Moreover, the inclusive element addresses the market development small actors (e.g. smallholder groups or organisations, small traders, retailers and agroprocessors) by stimulating local strategic partnerships. Against this background, a business model is inclusive when it integrates smallholders into markets with the underlying principle that there are mutual

${ }^{19}$ Inclusive market include different marginalised groups (e.g. women, youth, working-age disabled people and smallholders) on the demand side as clients/customers and on the supply side as employees, producers and business owners at various points along value chains. Ch. Gradl, C. Knobloch, Inclusive markets development. Brokering inclusive business models, United Nations Development Programme, New York 2010, p. 18.

${ }^{20}$ The OECD refers to inclusive growth as an economic growth that creates opportunity for all segments of the population and distributes the dividends of increased prosperity, both in monetary and non-monetary terms, fairly across society. The relevant dimensions of inclusive growth may vary across countries depending on their level of development, social preferences, specific conditions and circumstances. OECD, Making inclusive growth happen, Ford Foundation, OECD, Paris 2014, pp. 80-82.

21 According to M. Porter's and M. Kramer's creating shared value theory is a corporate policies and practices that enhance the competitiveness of a company while simultaneously advancing social and economic conditions in the communities in which the company sells and operates. Profit involving shared value enables society to advance and companies to grow faster. Key characteristics of this theory are: designing new products and services that meet social and environmental needs while simultaneously delivering a financial return; access to new markets; reconfiguring and securing the value chain by tapping new or better resources and partners to improve productivity; creating local clusters to strengthen and capture economic and social benefits at the community level. M. Porter, M. Kramer, Creating shared value, "Harvard Business Review" 2011, no. 1-2, pp. 62-77; C. Moore, Corporate social responsibility and creating shared value: what's the differrence?, Global Alliances and Strategic Initiatives, Atlanta 2014, pp. 3-5.

${ }^{22}$ E. Likoko, J. Kini, Inclusive business - a business approach to development, "Current Opinion in Environmental Sustainability" 2017, vol. 24, p. 84.

${ }^{23}$ T. Golja, S. Pozega, Inclusive business - what it is all about? Managing inclusive companies, "International Review of Management and Marketing" 2012, no. 1, vol. 2, p. 41.

${ }^{24}$ M. Heinrich-Fernandes, How to create an enabling environment for inclusive business?, The Donor Committee for Enterprise Development, Cambridge 2016, p. 1. 
benefits for poor farmers and the business community ${ }^{25}$. It is often emphasised that inclusive business model has the potential to create win-win solutions for profit-driven as well as social interests. Therefore, it can offer sustainable solutions to socio-economic and ecological challenges, independently of public resources ${ }^{26}$. It is particular as it strives to achieve both financial and social aims ${ }^{27}$. Sometimes, it must compensate for gaps in the market environment (e.g. a lack of market information, ineffective regional ecosystem, inadequate physical infrastructure, limited knowledge and skills, limited access to financial services), or work around them ${ }^{28}$. That makes, the model a highly significant concept for development cooperation in general, and cluster development in particular (tab. 1).

Inclusive business model take place at the intersection of business and development work $^{29}$. Its definition which was used within research and learning initiative PPPLab Food\&Water (commissioned by the Dutch Ministry of Foreign Affairs), include the core elements of all-inclusive business ${ }^{30}$ :

- firstly, there is an explicit effort to incorporate low-income population segments in the business initiative in various possible roles along the value chain,

- secondly, the initiative is integrated into core business strategy and processes, rather than being relegated to a niche domain of corporate social responsibility,

- thirdly, there is a business proposition that generates explicit value both for the company and the low-income segment involved.

Most scholars and practitioners claim that a business model is usually inclusive if it is credible, durable, equitable, effective, adaptable to the social needs, creates employment and has long-term financial and ecological sustainability. It is characterised by the willingness and extent to which businesses are willing to reduce their profit margin vertically and ensure systematic integration of the poor in a positive manner as providers of resources and services, and consumers of products ${ }^{31}$. Experts of International Finance Corporation World Bank Group argue, that inclusive business models are not limited to a type or size of business. Small and medium-size enterprises (SMEs), domestic companies of all sizes and even multinational corporations operating in developing countries can have inclusive business models ${ }^{32}$.

${ }^{25}$ S. Kelly, N. Vergara, H. Bammann, Inclusive business models. Guidelines for improving linkages between producer groups and buyers of agricultural produce, Food and Agriculture Organization of the United Nations, Rome 2015, pp. 1-3.

${ }^{26}$ U. Rösler, D. Hollmann, J. Naguib, A. Oppermann, Ch. Rosendahl, Inclusive business models, Deutsche Gesellschaft für Internationale Zusammenarbeit, Berlin 2013, pp. 11-33.

${ }^{27}$ M. Halme, S. Lindeman, P. Linna, Innovation for inclusive business: intrapreneurial bricolage in multinational corporations, "Journal of Management Studies" 2012, no. 49 (4), p. 746.

${ }^{28} \mathrm{Ch}$. Gradl, B. Jenkins, Tackling barriers to scale: from inclusive business models to inclusive business ecosystems, CSR Initiative at the Harvard Kennedy School, Cambridge 2011, p. 8.

${ }^{29}$ Ch. Gradl, C. Knobloch, Inclusive markets development ..., op. cit., p. 7.

${ }^{30} \mathrm{http} / / /$ www.snv.org/public/cms/sites/default/files/explore/download/partnerships_for_inclusive_ business_development.pdf (access: 1.11.2017).

${ }^{31}$ E. Likoko, J. Kini, Inclusive business ..., op. cit., pp. 85-68.

${ }^{32}$ International Finance Corporation, Policy note on the business environment for inclusive business models, World Bank Group, Washington 2012, p. 3. 
Table 1. The value of inclusive business model - selected aspects

\section{Inclusive business model:}

- creating sustainable livelihoods for the businesses and the local communities while integrating businesses, consumers and civil society

- facilitating the integration of smallholders into value chains

- chance of a competitive and inclusive value chain

- ensuring that the smallholders and SMEs are in a position to address their basic needs in economically, socially and environmentally sustainable ways

- generating sustainable and decent opportunities for groups with low or no job market mobility

- low-income populations can provide markets, workforce and that small-scale producers can strengthen the supply chain for businesses

- engaging the poor as producers, distributors, suppliers, or consumers can trigger the realization of socio-economic value and to strengthen livelihood opportunities for communities in commercially viable ways

- integrates smallholders into markets with mutual benefits for the poor and the business community while enabling the poor to move out of poverty

- support small enterprises and allows for long term diversified income streams

- support to smallholder-based business models results in poverty reduction, improved food security and more competitive agricultural value chains

- creating of opportunities by removing economic, social, ecological, and geographical barriers

- introducing innovation to business models, processes, products and services, such that they become more affordable and/or better tailored to the needs of the smallholders and small firms

- improving the quality and safety of products for local food markets

- provides a better way for social innovations and social entrepreneurship

- can be integrated in biodiversity offset policies

- inclusive development and moving smallholders out of poverty

- a key concept within the overtly pro-poor inclusive development approach

Source: prepared based on: E. Likoko, J. Kini, Inclusive business ..., op. cit., pp. 84-85; M. Virah-Sawmy, Growing inclusive business models in the extractive industries: Demonstrating a smart concept to scale up positive social impacts, "The Extractive Industries and Society" 2015, vol. 2, no. 4, p. 676; T. Golja, S. Pozega, Inclusive business .... op. cit., p. 25; D. Teneta-Skwiercz, The essence and meaning of inclusive business models, "Research Papers of Wroclaw University of Economics" 2016, no. 444, pp. 503-505.

Inclusive business within an agribusiness cluster means doing the business in a new way through recognition and implementation of inclusive business models, which are adequate to the cluster needs ${ }^{33}$. According to A. Rappoldt, M. Sopov and J. Guijt the inclusive agribusiness models can target all aspects and levels of the agri-food sector because inclusive agribusiness means deliberately shaping core business processes in the sector so that they address the needs of low-income disempowered parties, such as smallholder farmers and seasonal workers and create value for these groups as well as the SMEs ${ }^{34}$. Inclusive approaches within the agribusiness cluster is very important for cooperation in agricultural

${ }^{33}$ T. Golja, S. Pozega, Inclusive business .... op. cit., p. 41.

34 A. Rappoldt, M. Sopov, J. Guijt, Inclusive business models in agriculture, http://seasofchange. net/wp/wp-content/uploads/2017/04/2Theme_IBModels_corr2.pdf (access: 1.12.2017). 
value chains and achieving socio-economic goals of cluster members. The basic steps for implementing a inclusive business model approach are $\mathrm{to}^{35}$ :

- appraise the current business model - compare the separate business models of the farmer organisation and buyer,

- conducting a causal chain analysis to determine how the outputs of a business model are intended to link to desired outcomes,

- bringing together private, public and nongovernmental partners to foster value chain development,

- integrating cluster communities in the work of awareness creation, education and service delivery,

- overcoming development barriers through cluster cooperation,

- enhancing access to finance and other resources,

- facilitating and moderating partnerships between companies interested in inclusive business and potential partners,

- creating capacities and space for innovation \& research,

- adjustment of cluster activity to local/regional contexts, stakeholder needs, market structures and consumption trends,

- integrating the cluster members in the design and development (co-creation) of the valuable products and services,

- identify common upgrading priorities - prioritise upgrading needs that are common to both seller and buyer,

- design an upgraded business model - design interventions that respond to the common upgrading priorities identified,

- measure progress - set indicators to be measured on a continual basis (e.g. volumes traded between smallholders and target buyers, smallholder return on investment from business model and net margin increase, number of smallholders supplying produce through target groups, number of informal and formal contracts),

- maximising the commercial and social value of business models through effective advocacy and communications.

Cluster theory highlights opportunities for coordination and mutual improvement in areas of common partners concern ${ }^{36}$. Cluster coordinator/broker play an essential role in developing inclusive business models because he can support the cluster development at all stages, starting from market assessment and feasibility studies, via the development of a suitable business model, to implementation and evaluation. Moreover, he can help to identify suitable partners, support cluster members in acquiring resources, and bridging the different mindsets and facilitating the partnering process ${ }^{37}$.

The implementation of an inclusive business model within a cluster largely depends on strategic thinking and cluster management. This kind of model is based on innovation,

\footnotetext{
35 S. Kelly, N. Vergara, H. Bammann, Inclusive business models..., op. cit., pp. 19-24; E. Wach, Measuring the inclusivity of inclusive business, "IDS Practice Paper" 2012, no. 9, p. 13; T. Golja, S. Pozega, Inclusive business..., op. cit., pp. 28-29; International Finance Corporation, Policy note..., op. cit., pp. 1-2.

${ }^{36}$ U. Bronisz, W. Heijman, Competitiveness of Polish regional agro-clusters, "Applied Studies in Agribusiness and Commerce" 2008, no. 2 (1-2), p. 39.

${ }^{37}$ Ch. Gradl, C. Knobloch, Inclusive markets development ..., op. cit., pp. 7, 44.
} 
which makes innovation policy a relevant policy area for their support ${ }^{38}$. However, the success of inclusive business innovation does not depend only on innovators-clusterpreneurs ${ }^{39}$ or their ideas alone, but requires interplay between cluster ecosystem, clusterpreneurs and cluster members. An effective inclusive business model requires business partners to operate within legal frameworks that clearly stipulate the ownership of resources and sharing of risks and rewards ${ }^{40}$. Doing the business in an inclusive way is based on the multidimensional social responsibility and sustainable development. Without being responsible, the cluster members can not follow the inclusive business model ${ }^{41}$.

In the ecosystem of agribusiness cluster including large and SMEs, buyers, processors, food manufacturers and financial institutions, implement a range of inclusive solutions (e.g. working with farmers in groups, rather than individually, to reduce costs and simplify logistics, providing training and learning opportunities to improve quantity and quality of production, making it possible for farmers to access credit to cover operating costs and make investments) to overcome key barriers and procure from farmers in commercially viable ways ${ }^{42}$. An inclusive business model within a cluster leads to the continuous creation of employment opportunities for low-income communities-either directly or through cluster value chain as suppliers, distributors, retailers and service providers ${ }^{43}$. It stimulates cluster members into dynamic consumer markets and diverse new sources of supply. A close link between farmers and consumers can help to transfer information to farmers

${ }^{38}$ U. Rösler, D. Hollmann, J. Naguib, A. Oppermann, Ch. Rosendahl, Inclusive business ..., op. cit., p. 28.

39 The clusterpreneur is a key actor in the emergence of clusters. He can be seen as a constellation of four types of cluster members, e.g. universities and university-related institutions as a key institutions in both the knowledge-generating and the knowledge-diffusing systems, local government as a policy-makers, private firms and industry associations, business services and venture capital organisations. Active clusterpreneurs are relatively more important in less favoured regions, and that different clusterpreneurs may act effectively in different institutional settings and in different phases of cluster evolution. An important function of clusterpreneurs is thus to knit regional organisations together, not only in a physical sense by creating networks, but equally importantly by creating social capital. The role of active clusterpreneurs may vary over time, and will generally diminish when the cluster grows and develops its own dynamic development processes and networks. Therefore, clusterpreneurs are seen through the prism of proactively forming cluster processes and in doing so incorporating supporting organisations. J.L. Christensen, D. Stoerring, Facilitating cluster evolution in peripheral regions: the role of clusterpreneurs, [in:] Interactive learning for innovation. A key driver within clusters and innovation systems, B.T. Asheim, M.D. Parrilli (ed.), Palgrave Macmillan, London 2012, pp. 138-142. A clusterpreneur, typically needs to encourage synergies and build consensus, maintain the balance of achieving short vs. long-term benefits and focus on concrete action plans for specific cluster. T. Andersson, S. Schwaag-Serger, J. Sörvik, E. Wise, Cluster policies whitebook, International Organisation for Knowledge Economy and Enterprise Development, Lund 2004, p. 101. Individual clusterpreneur often takes role of cluster manager or cluster leader. In turn, institutional clusterpreneur is a cluster coordinator (cluster organisation).

${ }^{40}$ E. Sulle, R. Hall, G. Paradza, Inclusive business models in agriculture?, "Policy Brief" 2014, no. 66, p. 3 .

${ }^{41}$ T. Golja, S. Pozega, Inclusive business ..., op. cit., p. 23.

${ }^{42}$ K. Gaertner, E. Ishikawa, Shared prosperity through inclusive business, International Finance Corporation World Bank Group, Washington 2014, p. 7.

${ }^{43}$ V. Bonnell, F. Veglio, Inclusive business for sustainable livelihoods, "Fields Actions Science Reports" 2011, vol. 5, p. 2. 
on new market needs, trends in world agricultural production, and consumer preferences. Cooperation within agribusiness cluster value chain gives more opportunities for leading to improvements in both smallholders livelihoods, and the competitiveness of cluster value chain. Small cluster members are tied to input and output markets through a series of forward and backward business linkages within cluster cooperation. Inclusive business holds great promise but is still limited and there is an urgent need to find ways to replicate, scale, and encourage other companies to take action ${ }^{44}$. Experts of International Finance Corporation World Bank Group argue, that to support inclusive agribusinesses, governments can implement regulations that make agricultural markets more efficient ${ }^{45}$. National and local governments can also help small farmers organise into associations, cooperatives and clusters, enabling them to strengthen their market positions, brand, access inputs, training or financing, and work better with larger agribusinesses at home and abroad.

\section{CASE APPLICATION OF THE INCLUSIVE BUSINESS APPROACH WITHIN AGROBIO CLUSTER}

An inclusive business approach within an AgroBio Cluster shapes core business processes in the cluster organisation and cluster value chain so that they address the needs of low-income cluster members, such as smallholder farmers or local SMEs, and create value for all groups of cluster members through the sustainable development of cluster. It focuses on increasing productivity of smallholder farming, development of cluster value chain, and providing farmers with better market access or more stable and equitable trading conditions. A cluster can adopt key assumptions of the inclusive business model, allowing it to succeed in both benefiting the cluster members and socio-economic development of rural communities.

AgroBio Cluster is oriented to development of agri-food industry and bioeconomy. The cluster brings together local companies, local government administration, research and scientific institutes, as well as business support organisations, especially from South Mazovia (Polish region) and stimulates long-term international, interregional and inter-cluster cooperation.

AgroBio Cluster established in the period 2014-2015 within the cluster initiative that was financed from EU funds obtained for the project ORCHESTRA. The project was implemented in close cooperation with Spain and aimed at developing territorial partnerships, clusters and cross-sectoral collaboration. The main objective of the project was to boost development, animation and coordination of inter-sectoral cooperation and participation between the public sector, clusters and business to increase the competitiveness and adaptability of the companies and the south part of Mazovia region (Radom subregion). The specific goals of the projects were to:

- increase knowledge of local government institutions, clusters and business in terms of effective collaboration, partnerships and methodology for economic transformation based on Spanish solutions and experiences,

- improve the capacity of the public administration in the field of leading regional innovation policies and territorial strategies that boost regional competitiveness and socio-economic development processes,

\footnotetext{
${ }^{44}$ Ibidem, p. 5.

${ }^{45}$ International Finance Corporation, Policy note ..., op. cit., p. 6.
} 
- transfer Spanish experiences in field of territorial strategy-making, governance, clusters and cooperation network using participatory methodologies, cross-sectoral engagement and cogeneration of knowledge,

- implement pilot actions in local governments using Spanish solutions adapted to local economic and social reality and organising dissemination activities for public, private and scientific institutions that widen participation and co-responsibility of territorial development.

The target group of the ORCHESTRA project were representatives of local and regional governments (110) together with representatives of business, chamber of commerce, academic staff of the universities, clusters and innovation network and NGOs. In order to ensure generation of technological, economic, social and marketing synergy effects, the project was open to representatives of public, private and NGOs involved in development of Radom region that include the following counties: Radom city, Przysucha, Zwolen, Białobrzegi, Szydłowiec, Lipsko, Kozienice.

The ORCHESTRA project consisted in several activities related to the promotion of cooperation mechanisms, clustering, participation and intersectoral partnerships through:

- organisation of opening conference with 60 participants from public, private, scientific and NGOs,

- preparation of five thematic reports tailored to the needs of the Radom region and based on Spanish experiences and Polish needs in terms of effective cooperation and competitiveness,

- organisation of three participative workshops where more than 150 representatives of public administration worked together on identification of local needs, expectation, existing potential and possible development paths,

- advisory and e-mentoring of Spanish partners during 20 pilot implementations,

- participation in the closing conference and dissemination of project activities.

During the implementation of project actions, agri-food potential was clearly identified as a one of the strategic and most promising sectors for cluster development.

The cluster strategy was developed as a project pilot implementation together with Spanish e-mentoring and advisory. It is based on six complementary axis:

- integration of private, public and scientific institutions aimed at joining join the inter-sectoral potential of local entities, creating unique relationships that foster the creation of innovations, $\mathrm{R} \& \mathrm{D}$ and new interlinks development,

- innovation in terms of new products, processes and marketing that support the development and implementation of value-added novelties that build competitive advantage of cluster members,

- internationalisation and international expansion (including export promotion) that help to access international markets, creating cooperative partnerships at international level for cluster members,

- new areas of cooperation for a joint action or a joint resolution of common problems that help cluster partners to solve common problems or to collaborate in a particular area,

- new UE projects for individual and group development where cluster management helps to identify national and international funding to finance common activities, 
- using the new tools of marketing and effective cooperation that encourage creative use of traditional tools of communication and multimedia to enhance the corporate image of cluster members on internal and external market.

The key aim of the cluster is to strengthen the capacity of the industry in an interdisciplinary way and accelerate the development of agriculture bio-economy through:

- identification of shared competences and cooperation areas of the cluster members,

- initiating the creation of products with added value resulting from the joint capacities and its commercialisation on domestic and foreign markets,

- transfer of knowledge, technology and international exchange of experience,

- building links between sectoral and cross-sectoral clusters and their members and establishing synergies with clusters and networks with related industries (chemicals, cosmetics, life science, renewable energy, IT),

- initiating joint ventures and projects co-financed from EU funds, both on domestic and international field,

- organisation of promotional, education, training and information activities,

- internationalisation activity of the cluster and its members.

AgroBio Cluster gathers 47 members including 33 SMEs, 1 large firm, 3 entities from R\&D sector, 4 representatives of local government units and 6 business support organisations that share common values and are located especially in the Mazovia region. The general view of cluster enterprises is shown in chart 1 .

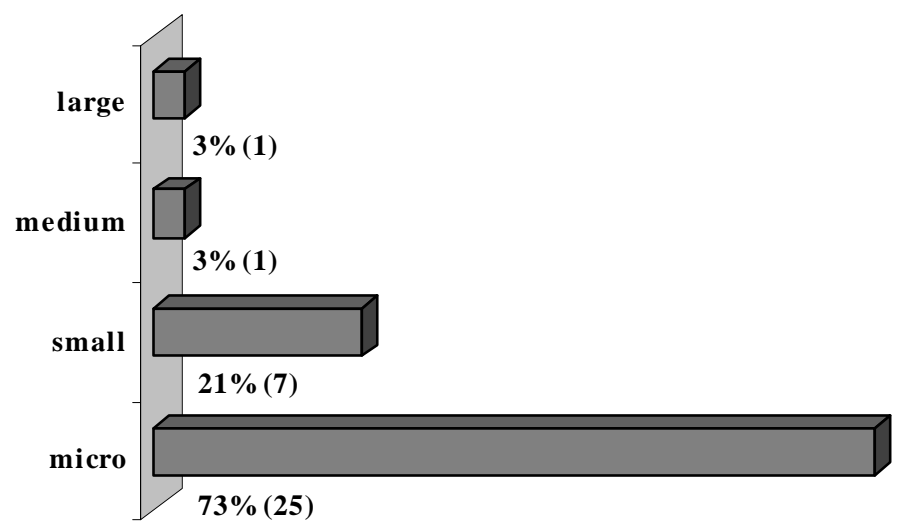

Chart 1. Structure of business within AgroBio Cluster by enterprises size (1.12.2017)

Source: Own elaboration.

The largest group of cluster members represent 34 companies related to fruit and vegetable production, especially apples, peppers, cherries, eggplants, rhubarb and soft fruits. Cluster is also composed by fresh fruit and vegetable distributors, buying agents, agribusiness agencies and catering companies, as well as agricultural machinery and sorting equipment manufacturers and food safety technology providers. In terms of R\&D, science and education, cluster cooperates with research institute of horticulture, private university specialises in public health and vocational school in the fields of food \& beverage management 
and hospitality. AgroBio Cluster also collaborates with local public administration and several service providers in the fields of technology scouting, export promotion and foresight studies. In order to boost cross-sectoral synergies, AgroBio Cluster organised several interrelated activities involving cluster managers, coordinators, public and scientific institutions and SMEs. Examples of those actions are the following:

- establishment of close cooperation with the Mazovian Chemical Cluster and establishment of areas cooperation between agro-food, chemical and cosmetic sectors,

- organisation of a series of participatory workshops in Warsaw, Cedzyna and Paprotnia that allowed for analysis of agri-food industry development,

- organisation of the study visit from the province Podkarpackie region in the Radom region within EU-funded project related to business-science cooperation,

- participation in the European Cluster Conference 2014 and international promotion of cluster and its members (Brussels, 21-22 October 2014),

- participation in working groups within the regional smart specialisation (RIS3) related to food safety.

In order to assure the quality of cluster management, AgroBio Cluster was benchmarked on February 2015 according to a benchmarking approach developed and performed by the "European Secretariat for Cluster Analysis" of VDI/VDE Innovation + Technik GmbH. ESCA is the European Secretariat for Cluster Analysis and supports in particular cluster managers and policy makers with advice on cluster development. ESCA experts have developed a methodology for cluster benchmarking that is acknowledged by both cluster managers and policy makers throughout Europe. Since 2008 more than 700 cluster management organisations have been benchmarked according to this methodology ${ }^{46}$. The objective of the benchmarking exercise was to provide cluster organisations with a better understanding of how to improve the quality and effectiveness of the work done by cluster organisations as well as how to facilitate international collaboration between clusters.

Benchmarking results are based on information provided by the cluster manager to an external benchmarking expert. The interview covered 36 indicators with regard to the structure of the cluster, the cluster management and the governance of the cluster, financing of the cluster management, services provided by the cluster management, contacts and interaction within the cluster and achievements, and recognition of the cluster. By participating in this benchmarking AgroBio Cluster has expressed its interest in striving for cluster excellence and was awarded with the European Cluster Management Excellence label in bronze. Coordinator of AgroBio Cluster also received a pack of recommendations that included:

- to establish relations with mature cluster organisations (transfer of experiences),

- to organise the cluster or the cluster organisation within a legal framework,

- suggestions in terms of definition of the cluster manager activity (role, tasks and functions) and implementation of a governing body like a steering committee, advisory board, etc., as well as degree of involvement of the participants of the cluster in the decision making,

- to develop and implement a cluster strategy in order to operate in a sustainable and successful way,

- to find new financial sources should be combined with an internal strategy process,

\footnotetext{
${ }^{46} \mathrm{https}$ ://www.cluster-analysis.org/ (access: 1.11.2017).
} 
- to develop new services for cluster members related to funding, collaborative technology development, international matchmaking and networking with external partners in Poland and abroad.

For AgroBio Cluster and its members the benefits from the certificate included: international promotion of the cluster and its members, as well as increased visibility of the Radom region; credibility, prestige and ease of establishing partnerships and consortia for EU projects (including the Horizon 2020); easier access to new foreign markets for agrifood entrepreneurs and acquiring new partners for cooperation.

During 2015-2017 AgroBio Cluster participated in several national and international events, training seminars and conferences related to cross-cluster cooperation, internationalisation and value proposition development, such as:

- 4th Cluster-to-Cluster Conference held in Warsaw aimed at providing a cluster-to-cluster forum for developing ideas for international collaboration and organisation matchmaking sessions for 250 participants representing 150 different clusters from 30 European countries,

- R\&D techBrainers Summit 2016 with the moderation of Future Food expert group aimed at identifying challenges related to food safety, health and creation of new products in synergy with connected sectors, such as packaging, IT and chemical,

- participation in working groups related to Regional Smart Specialisations (RIS3) organised by Mazovian regional government and aimed at co-creating R\&D agenda and implement smart specialisation strategies,

- participation at Mazovia Development Forum as official partner of the biggest event organised by Mazovian regional government, where AgroBio Cluster was responsible for organisation and animation of Smart Business Zone: Innovations, Internationalisation and Cluster Development,

- network partner EIT Food (European Institute of Innovation and Technology) project FoodConnects - a consortium of 50 partners from leading businesses, research centres and universities across 13 countries aimed at transforming European food system, driving consumer confidence and improved global health.

In 2016 two projects aimed at developing AgroBio Cluster were implemented. The first one "INNO ${ }^{+}$- partnership, cooperation and innovation for AgroBio Cluster development" was aimed at developing a partnership between cluster members, stimulating cooperation networks and activating co-operation between science and business. Special emphasis was put on initiating product, marketing and process innovations with added value resulting from shared capacities, cross sectoral links and interdisciplinary strengthening of R\&D. The main objectives of the project were:

- to boost cooperation between cluster members by combining existing capabilities, building mutual trust and unique interrelations needed to create new business,

- to stimulate partnerships aimed at creating value-added products that help building competitive advantage for cluster members and partners (innovation),

- to activate co-operation between science and business, supporting technology and knowledge transfer from R\&D institutes to industry.

The second project called "INTER ${ }^{+}$- partnership, cooperation and internationalisation for AgroBio Cluster development" was aimed at building an international cooperation network, preparing cluster members for the internationalisation process, joint export promotion and participation in international research and development project consortia. 
The project was also focused on sectoral and cross sectoral links between the cluster and its members at international and interregional level.

Currently, the cluster is in the development phase focusing on building a full value chain and networking with related industries (i.e. chemistry, cosmetics, packaging \& design, life science, prototyping, biotechnology, manufacturing, etc.) to pursue strategic goals and added-value resulting from cross-sectoral synergies. Good practices from international partners identified by past projects within supporting the business models of smallholder groups and small buyers surely help to extend the value chain and overcome shortcomings within development of inclusive business model in the cluster.

\section{CONCLUSIONS}

Agribusiness is a very important sector of the economy of many countries, including Poland. Entities of this sector whose activity is focused on a given territory through mutual connections with their partners in value chains (e.g. formal and informal, vertical and horizontal) may be co-created by agribusiness clusters. Functioning in the structure of these clusters means that individual members, including agricultural producers, can more effectively identify potential opportunities and threats posed by a turbulent environment and make more rational decisions that allow them to obtain optimal benefits.

One of the drivers of changes, oriented to the socio-economic development of agribusiness cluster is the inclusive business model. Realising the ambitious assumptions of this model is nowadays treated as a strategic challenge. It requires effective management of the cluster, strategic thinking, involvement of the coordinator and cluster members as well as real support from external stakeholders, such as public authorities (local and national government) and investors. The foundation of the inclusive business model in the cluster is primarily related concepts such as corporate social responsibility, sustainable development, shared value and value chain management.

The results of theoretical and empirical research presented in the article justify the need to implement inclusive business within agribusiness cluster, especially in less developed regions. At the same time, they allow formulating a number of conclusions in this regard, such as:

- inclusive bonds, connecting different people and organisations in the cluster has an impact on the quality and intensity of cluster cooperation,

- cluster as an inclusive group is open to new partners, which means that the cluster willingness to belong to it is decisive,

- cluster as an inclusive system is a value in itself, as it fosters the creation of an entrepreneurial ecosystem based on social capital,

- a more inclusive approach in cluster management enables a complete use of the cluster strategic potential and at the same time reduces the problem of social exclusion in the cluster rooting,

- implementation of the inclusive business model in clusters can stimulate the development of an inclusive economy, including strengthening economic, social and territorial cohesion,

- the correlation of income growth and social goals in the cluster favours the successful implementation of the inclusive business model and the creation of an inclusive business ecosystem, 
- involvement of the poorer part of the society living in the territory of rooting the cluster in its activities in various ways may be a source of cluster resources and contribute to the elimination of the problem of exclusion from the labour market,

- inclusive business model should be adequate to the needs and possibilities of the cluster and its territory of rooting,

- often in Polish clusters, activities bearing the characteristics of the inclusive business model are undertaken, although their members and coordinators do not use this term.

The inclusive business model within the agribusiness cluster is still a new area of research, poorly grounded in Polish scientific literature. Thus, the article attempts to provide a synthetic illustration of the results obtained. However, all issues related to the analysed research problem have not been exhausted. Many of the issues presented require further detailed research and analysis. The existing gaps in knowledge in this area may inspire researchers to learn more about these issues in different fields of science. Certainly, it can be said that this research topic can develop dynamically in the near and distant future. Possible directions for further empirical research include taking into account different practices and experiences (positive and negative) in the scope of cluster inclusion and identification of key barriers to the implementation of the inclusive business idea in their environment in domestic and foreign space. Due to the fact that the presented research results and conclusions refer mainly to the specifics of agribusiness clusters, the more important step is the identification of which cluster industry is most conducive to the development of inclusive business, and which is the least.

\section{REFERENCES}

[1] Alhassan A., Bapule J.S., Gyasi O., Mills G.A., Nketiah J., Yeboah R., Facilitating agribusiness cluster development at grassroot level, International Centre for Development Oriented Research in Agriculture, Wageningen 2007.

[2] Alidou M., Lem M., Schrader T., Zeeuw F., Local entrepreneurship, agribusiness cluster formation and the development of competitive value chains, Berenschot, Koutiala 2010.

[3] Andersson T., Schwaag-Serger S., Sörvik J., Wise E., Cluster policies whitebook, International Organisation for Knowledge Economy and Enterprise Development, Lund 2004.

[4] Bonnell V., Veglio F., Inclusive business for sustainable livelihoods, "Fields Actions Science Reports" 2011, vol. 5, pp. 1-5.

[5] Bronisz U., Heijman W., Competitiveness of Polish regional agro-clusters, "Applied Studies in Agribusiness and Commerce" 2008, no. 2 (1-2), pp. 35-40.

[6] Christensen J.L., Stoerring D., Facilitating cluster evolution in peripheral regions: the role of clusterpreneurs, [in:] Interactive learning for innovation. A key driver within clusters and innovation systems, B.T. Asheim, M.D. Parrilli (ed.), Palgrave Macmillan, London 2012.

[7] Clark Ch., Rudder J., Javid K., Lawrence A., Neidhart M., Biscaye P., Panhorst-Harris K., Reynolds T., Anderson C.L., Agribusiness development clusters, Evans School of Public Affairs, University of Washington, Evans School Policy analysis and Research, Seattle 2015.

[8] Dioula B.M., Deret H., Morel J., Vachat E., Kiaya V., Enhancing the role of smallholder farmers in achieving sustainable food and nutrition security, International Conference on Nutrition - better nutrition better lives, Paris 2013. 
[9] Dorzhieva E., Dugina E., The formation of agro-food clusters as a competitiveness growth factor, "International Journal of Economics and Financial Issues" 2015, no. 5, pp. 238-247.

[10] Gaertner K., Ishikawa E., Shared prosperity through inclusive business, International Finance Corporation World Bank Group, Washington 2014.

[11] Galvez-Nogales E., Agro-based clusters in developing countries: staying competitive in a globalized economy, Food and Agriculture Organization of the United Nations, Rome 2010.

[12] Geldes C., Felzensztein Ch., Turkina E., Durand A., How does proximity affect interfirm marketing cooperation? A study of an agribusiness cluster, "Journal of Business Research" 2015, no. 68, pp. 263-272.

[13] Golja T., Pozega S., Inclusive business - what it is all about? Managing inclusive companies, "International Review of Management and Marketing" 2012, no. 1, vol. 2, pp. 22-42.

[14] Gradl Ch., Jenkins B., Tackling barriers to scale: from inclusive business models to inclusive business ecosystems, CSR Initiative at the Harvard Kennedy School, Cambridge 2011.

[15] Gradl Ch., Knobloch C., Inclusive markets development. Brokering inclusive business models, United Nations Development Programme, New York 2010.

[16] Halme M., Lindeman S., Linna P., Innovation for inclusive business: intrapreneurial bricolage in multinational corporations, "Journal of Management Studies" 2012, no. 49 (4), pp. 743-784.

[17] Heinrich-Fernandes M., How to create an enabling environment for inclusive business?, The Donor Committee for Enterprise Development, Cambridge 2016.

[18] http://www.snv.org/public/cms/sites/default/files/explore/download/partnerships_for_inclusive_business_development.pdf (access: 1.11.2017).

[19] https://www.cluster-analysis.org/ (access: 1.11.2017).

[20] https://www.missourieconomy.org/pdfs/agribusiness.pdf (access: 1.11.2017).

[21] International Finance Corporation, Policy note on the business environment for inclusive business models, World Bank Group, Washington 2012.

[22] Kelly S., Vergara N., Bammann H., Inclusive business models. Guidelines for improving linkages between producer groups and buyers of agricultural produce, Food and Agriculture Organization of the United Nations, Rome 2015.

[23] Likoko E., Kini J., Inclusive business - a business approach to development, "Current Opinion in Environmental Sustainability" 2017, vol. 24, pp. 84-88.

[24] Molema M., Segers Y., Karel E., Introduction: Agribusiness clusters in Europe, $19^{\text {th }}$ and $20^{\text {th }}$ Centuries, "The Low Countries Journal of Social and Economic History" 2016, no. 13 (4), pp. 1-16.

[25] Moore C., Corporate social responsibility and creating shared value: what's the differrence?, Global Alliances and Strategic Initiatives, Atlanta 2014.

[26] OECD, Making inclusive growth happen, Ford Foundation, OECD, Paris 2014.

[27] Pietkiewicz I., Smith J.A., A practical guide to using interpretative phenomenological analysis in qualitative research psychology, "Psychological Journal" 2012, no. 18 (2), pp. 361-369.

[28] Porter M., Kramer M., Creating shared value, "Harvard Business Review" 2011, no. 1-2, pp. 62-77. 
[29] Ramon-Munoz R., The growth of an agribusiness cluster in Catalonia: evidence from the Olive Oil Industry, "The Low Countries Journal of Social and Economic History" 2016, no. 13 (4), pp. 41-66.

[30] Rappoldt A., Sopov M., Guijt J., Inclusive business models in agriculture, http://seasofchange.net/wp/wp-content/uploads/2017/04/2Theme_IBModels_corr2.pdf (access: 1.12.2017).

[31] Rösler U., Hollmann D., Naguib J., Oppermann A., Rosendahl Ch., Inclusive business models, Deutsche Gesellschaft für Internationale Zusammenarbeit, Berlin 2013.

[32] Shabazian D., Ballard-Rosa G., Holmqvist A., Ormiston L., Food and Agriculture cluster assessment, The Sacramento Area Council of Governments, Sacramento 2016.

[33] Sobol A., The perspectives for eco-clusters development in Poland, "Central and Eastern European Journal of Management and Economics" 2016, vol. 4, no. 1, pp. 63-80.

[34] Sulle E., Hall R., Paradza G., Inclusive business models in agriculture?, "Policy Brief" 2014, no. 66.

[35] Teneta-Skwiercz D., The essence and meaning of inclusive business models, "Research Papers of Wroclaw University of Economics" 2016, no. 444, pp. 500-511.

[36] Theus F., Zeng D., Agricultural clusters [in:] Agricultural innovation systems, The World Bank, Washington 2012.

[37] Virah-Sawmy M., Growing inclusive business models in the extractive industries: Demonstrating a smart concept to scale up positive social impacts, "The Extractive Industries and Society" 2015, vol. 2, no. 4, pp. 676-679.

[38] Wach E., Measuring the inclusivity of inclusive business, "IDS Practice Paper" 2012, no. 9.

\section{INKLUZYWNY MODEL BIZNESU - WYZWANIE STRATEGICZNE W ZARZĄDZANIU KLASTREM AGROBIZNESU}

Celem artykułu jest przedstawienie kluczowych założeń inkluzywnego modelu biznesu oraz uzasadnienie jego zastosowania w klastrze agrobiznesu. Rozważania naukowe prowadzono na podstawie wyników badań teoretycznych i empirycznych. Punktem wyjścia w przyjętym zakresie rozważań było powszechnie znane stwierdzenie, że klastry sprawnie zarządzane mogą kształtować konkurencyjność nie tylko swoich członków, ale także gospodarki oraz przyczyniać się do wzmocnienia spójności gospodarczej, społecznej i terytorialnej.

Artykuł składa się z trzech integralnych części, w ktorych scharakteryzowano strategiczny wymiar klastra agrobiznesu, istotę i znaczenie inkluzywnego modelu biznesu oraz dotychczasowe doświadczenia klastra Agro-Bio w obszarze implementacji tego modelu. Autorzy wykazują, że koncepcja klastra agrobiznesu dostarcza solidnych podstaw do przyjęcia nowego sposobu myślenia o kreowaniu konkurencyjności podmiotów gospodarki żywnościowej z uwzględnieniem potrzeb i wartości społecznych. Różne rodzaje klastrów, a w szczególności klastry agrobiznesu mogą tworzyć grupy inkluzywne z chwilą, gdy zapewnione jest $\mathrm{w}$ ich środowisku otwarte członkostwo, a o przynależności do klastra decyduje chęć wspólpracy klastrowej. Kluczowym czynnikiem rozwoju klastrów są więzi inluzywne, które łączą ludzi i organizacje z różnych środowisk. Tym samym determinuują jakość i intensywność partnerstwa w klastrze, wzmacniając zaangażowanie społeczności klastrowej. Te i inne przesłanki zaprezentowane w artykule, odnoszące się do specyfiki funkcjonowania klastra agrobiznesu, potwierdzają dobitnie, że inkluzywny model biznesu może okazać się wartościowym narzędziem w procesie realizacji celów klastra, szczególnie w regionach słabiej rozwiniętych (peryferyjnych). Pomimo, że implementacja tego modelu stanowi wciąż strategiczne wyzwanie w zarządzaniu klastrem, to liczne jego praktyczne walory 
uzasadniają słuszność koncentrowania wysiłku koordynatora i członków klastra na rzecz kształtowania inkluzywnego biznesu i zrównoważonego łańcucha wartości klastra. W procesie tym niezbędne jest wymierne wsparcie publiczne, zarówno o charakterze finansowym, jak i pozafinansowym.

Słowa kluczowe: klaster, agrobiznes, inkluzywny, zarządzanie, wartość, rozwój.

DOI: 10.7862/rz.2017.hss.63

Przestano do redakcji: czerwiec 2017 r.

Przyjęto do druku: grudzień 2017 r. 
